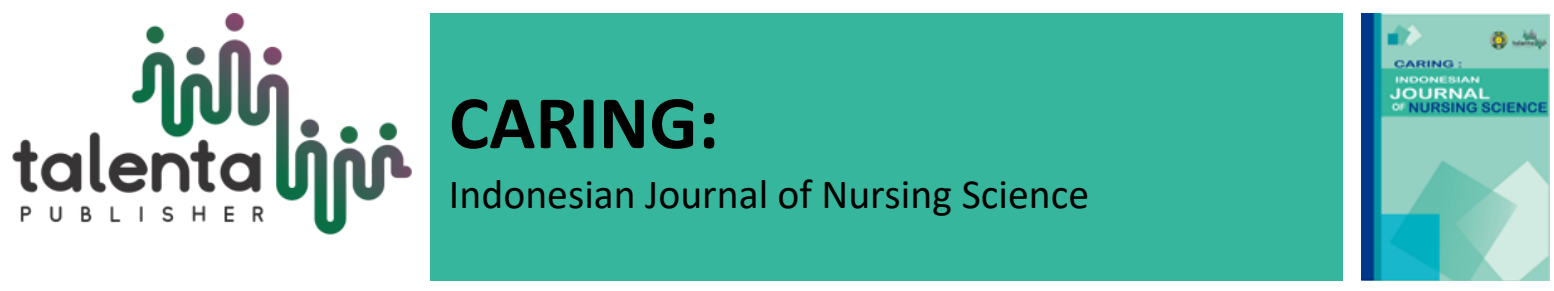

\title{
The Determination of Visual Inspection in Women of Childbearing Age
}

\author{
Fatwa Imelda ${ }^{1}$, Mula Tarigan ${ }^{2}$, Lidya Eryunika ${ }^{3}$ \\ ${ }^{1,2,3}$ Faculty of Nursing, Universitas Sumatera Utara, Medan, Indonesia
}

\begin{abstract}
Cervical cancer is the most common disease affecting women around the world. Early detection of cervical cancer is needed by using Visual Inspection with Acetic Acid (VIA). This method is relatively easy to do, and the examination costs are also quite affordable, making it more beneficial for women. This study was to determine the determinants of the VIA Test results. It is quantitative research with a descriptive approach presented in the form of a frequency distribution table. There are 100 samples of women of childbearing age acquired by purposive sampling at Patumbak District, Deli Serdang. From the samples, some respondents receive positive IVA test result as follows: 14\% aged 36-35 years old, 14\% Protestant, 19\% married, $9 \%$ high school graduates, $10 \%$ housewife, $15 \%$ with minimum monthly income, $12 \%$ with 3-5 children, $17 \%$ has multigravida parity, $14 \%$ married at the age of 17-25 years old, $12 \%$ first-time mother at the age of $17-25$ years old, and $14 \%$ with 5+ years using IUD contraception. The study was based on the negative VIA test result but with detected precancerous lesions. Further research with different variables is necessary to acquire more information regarding cervicitis incidence causes, thus, reducing cervical cancer numbers.
\end{abstract}

Keywords: cervical cancer; determinants; VIA test; women of childbearing age

Received $26^{\text {th }}$ April $2021 \mid$ Revised $28^{\text {th }}$ June $2021 \mid$ Accepted $12^{\text {th }}$ July 2021

*Corresponding author : Jl. Prof. T. Maas No.3, Padang Bulan, Kec. Medan Baru, Medan, Sumatera Utara

E-mail address: fatwa.imelda@usu.ac.id

Copyright (C) 2021

Published by Talenta Publisher, e-ISSN: 2685-7162

Journal Homepage: https://talenta.usu.ac.id/IJNS 


\section{Introduction}

Cervical cancer attacks the female reproduction genital, the cervical, or the birth canal, with a high mortality rate due to most women, are unaware and do not fathom the symptoms. Many women are diagnosed with late stadium cervical cancer and feeling unpleasant symptoms in their bodies. They visited the health service only to check their health condition but not getting a screening test to check their cervicals. Thus, they receive late treatment for a cure (Aprianti, et al., 2018). In addition, health problems have always been the main problem in all countries, even worldwide. It affects women of childbearing age, starting from adolescents to elders. One of the health problems with the second-highest prevalence rate is cervical cancer, next to women's breast cancer (Irianto, 2018).

Global Burden Cancer data pointed out that the incidence number of cervical cancers worldwide in 2012 was $16 / 100,000$ population. Malawi is the highest prevalence rate of cervical cancer cases with $75 / 100,000$ population (Globocan, 2012). Every year, more than 266,000 women died from the disease, and more than $85 \%$ death rate occurred in low-and middle-income countriesincluding Indonesia (Globocan International Agency, 2012). In 2013, around 98,692 women patients had cervical cancer. The latest data released by the Indonesia Ministry of Health shows $23.4 / 100,000$ population suffered from cervical cancer. The average mortality rate is $13.9 / 100,000$ population (Ministry of Health Republic of Indonesia, 2017).

The increasing yearly number of people with cervical cancer in Indonesia becomes a significant threat to the health world. The reason is the people with cervical cancer are only detected lately. At the same time, their cervical cancer has developed into the advanced stage. Cervical cancer can be treated earlier through early detection by doing the regular visual inspection with acetic acid (VIA) test or performing pap smear accompanied by Human Papillomavirus (HPV) vaccination to minimize the risks of cervical cancer. Besides, people can prevent cervical cancer by maintaining a healthy lifestyle and diet, avoiding fast food, quitting smoking and drinking alcohol, avoiding sexual intercourse with many sex partners, and learning how to choose and use good sanitary pads (Setiawati, et al., 2017).

Several factors can increase the incidence numbers of cervical cancer, such as high parity with short interpregnancy intervals, early marriage or earlier initiation of sexual intercourse, active and passive smoking, long-term use of oral contraception (5+ years), and low socioeconomic status (Imelda \& Nasution, 2020). Other risk factors triggering cervical from the VIA test method conducted to 100 respondents are as follow: $48 \%$ positive for cervical precancerous lesions, $74 \%$ aged $\geq 35$ years old, $68 \%$ had parity $<3$ times, $67 \%$ had first sexual intercourse at the age of $<20$ years old, $94 \%$ have one sex partner, $96 \%$ did not smoke, and $78 \%$ used contraceptive pills $<4$ years (Dugue, et al., 2015). In addition, women consuming combined progesterone-estrogen 
contraceptives are at risk of cancer 17,875 times more than women who do not consume the combined contraceptive (Farida, 2017).

Early detection can be conducted in several ways. First, using the smear method on the cervix's surface is known as the pap smear method, according to Papanicolau. Second, using the most straightforward method, the VIA test. The VIA test is the easiest way to diagnose cervical cancer. It uses a speculum inserted into the vagina to see the cervix smeared with 3\%-5\% acetic acid. It is the easiest and the most affordable method, making it more beneficial for women (Nurwijaya, 2010). If the acid hits the abnormal cells, the cervix tissue's color will turn white - meaning the resulting test is positive. The result shows that there are precancerous signs on the cervix. As in a World Health Organization report, the detection of precancerous lesions using the VIA test resulted in 66\%-96\% sensitivity and 64\%-98\% specificity. The positive or negative predictive value of the test is between 10\%-20\% and 92\%-97\%, respectively (Abduljabbar et al., 2014).

\section{Research Method}

The study was quantitative with a descriptive approach and conducted in Patumbak District, Deli Serdang. One hundred women of childbearing age are taken as samples using purposive sampling. The inclusion criterion is women aged 17-55 years old, married, and women who have had sex. The sampling formula was the Slovin formula. The data were collected using a questionnaire resulting in the respondent's characteristics and the VIA result test observation sheet. During the VIA test method: 1) you will lie on your back with opening legs (lithotomy);2) an examiner will insert a duck-bill-shaped device known as a speculum into the vagina; 3 ) then, the examiner will dip a cotton swab (cotton-bud-like apparatus) into a 3\%-5\% acetic acid solution (vinegar). Before conducting this study, the researcher has received ethical approval from the Ethics Commission of the University of North Sumatra No.176/KEP/USU/2020.

\section{Research Results}

Out of 100 respondents studied, $50 \%$ are in early adulthood, $74 \%$ protestant, $87 \%$ are Batak, 98\% married, $43 \%$ housewives, and $85 \%$ have an average monthly income less than regional minimum wage.

Table 1. The Respondent's Demographic Data Frequency Distribution $(n=100)$

\begin{tabular}{ccc}
\hline Variable & f & \% \\
\hline Age (years) & & \\
$17-25$ & 10 & 10 \\
$26-35$ & 50 & 50 \\
$36-45$ & 29 & 29 \\
$46-55$ & 11 & 11 \\
\hline
\end{tabular}


Table 1 (Cont.)

\begin{tabular}{lcc}
\hline Variable & f & $\%$ \\
\hline Religion & 74 & 74 \\
$\quad$ Protestant & 26 & 26 \\
$\quad$ Islam & & \\
Ethnicity & 87 & 87 \\
Batak & 1 & 1 \\
Karo & 4 & 4 \\
Nias & 2 & 2 \\
Dayak & 6 & 6 \\
Java & & \\
Marital status & 98 & 98 \\
Married & 2 & 2 \\
Widow & & \\
Education & 12 & 12 \\
Junior high school & 59 & 59 \\
Senior high school & 29 & 29 \\
$\quad$ College & & \\
Occupation & 14 & 14 \\
Civil officer & 10 & 10 \\
Private employee & 4 & 4 \\
Trader & 43 & 29 \\
Housewife & 29 & 85 \\
Others & & 15 \\
Family's monthly income & 85 & \\
$\quad$ r regional minimum wage & 15 & \\
$\quad>$ regional minimum wage & &
\end{tabular}

As Table 2 shown below, the respondent's characteristics are as follow: $52 \%$ had 3-5 children, $88 \%$ had multigravida, $90 \%$ married at the age of late adolescence, $87 \%$ had the first child at the age of late adolescence, $86 \%$ used contraceptives for $<5$ years, 59\% used implanted contraceptives, $17 \%$ used IUD, 15\% used injected contraceptives, and 9\% consumed contraceptive pills. Furthermore, all respondents have undergone the VIA test.

Table 2. The Respondent's Characteristics Frequency Distribution $(\mathrm{n}=100)$

\begin{tabular}{lcc}
\hline Variable & f & \% \\
\hline Number of children & & 44 \\
$0-2$ & 44 & 52 \\
$3-5$ & 52 & 4 \\
$6-8$ & 4 & \\
Number of parities & & 12 \\
$\quad$ Primigravida & 12 & 88 \\
$\quad$ Multigravida & 88 & \\
Married age & & 90 \\
17-25 years & 90 & 10 \\
26-35 years & 10 & 87 \\
Age at first having children & & 13 \\
17-25 years & 87 & \\
$26-35$ years & 13 & 86 \\
Length of using contraceptives (years) & & 14 \\
$\quad<5$ & 86 & \\
$\quad>5$ & 14 & \\
\hline
\end{tabular}


Table 2 (Cont.)

\begin{tabular}{lcc}
\hline Variable & f & \% \\
\hline Type of contraceptives & 17 & 17 \\
IUD & 9 & 9 \\
Pills & 15 & 15 \\
Injections & 59 & 59 \\
Implant & & \\
VIA test & 100 & 100 \\
$\quad$ Yes &
\end{tabular}

The VIA test result of 100 respondents shows $19 \%$ of respondents have positive results while $81 \%$ are negative. (Table 3 )

Table 3. VIA Test Results Frequency Distribution $(\mathrm{n}=100)$

\begin{tabular}{lcc}
\hline Variable & f & \% \\
\hline VIA test results: & & \\
Positive & 19 & 19 \\
Negative & 81 & 81 \\
\hline
\end{tabular}

The cross-tabulation below shows respondents with positive VIA test results as follow: at the age of 36-45 years old (14\%), Protestant (14\%), married (19\%), high school educated (9\%), housewives (10\%), having monthly income less than regional minimum wage (15\%), having 3-5 children (12\%), having multigravida (17\%), married at the age of 17-25 years old (14\%), having the first child at the age of 17-25 years old (12\%), >5 years using contraceptives (10\%), and using IUD-type contraceptive (10\%).

Table 4. Cross-tabulation of respondent characteristics with VIA test results $(n=100)$

\begin{tabular}{lccccc}
\hline Variable & Number & \multicolumn{3}{c}{ VIA test result } \\
& & Positive & Negative \\
& & & & f & \% \\
\hline Age (years) & 10 & 0 & 0 & 0 & 0 \\
$17-25$ & 50 & 1 & 1 & 49 & 49 \\
$26-35$ & 29 & 14 & 14 & 15 & 15 \\
$36-45$ & 11 & 3 & 3 & 8 & 8 \\
$46-55$ & & & & & \\
Religion & 74 & 11 & 11 & 63 & 63 \\
$\quad$ Protestant & 26 & 8 & 8 & 18 & 18 \\
Islam & & & & & \\
Ethnicity & 87 & 14 & 14 & 73 & 73 \\
Batak & 1 & 0 & 0 & 0 & 0 \\
Karo & 4 & 2 & 2 & 2 & 2 \\
Nias & 2 & 0 & 0 & 0 & 0 \\
Dayak & 6 & 3 & 3 & 3 & 3 \\
Java & & & & & \\
Marital status & 98 & 19 & 19 & 79 & 79 \\
Married & 2 & 0 & 0 & 0 & 0 \\
Widow & & & & & \\
Education & 12 & 6 & 6 & 6 & 6 \\
$\quad$ Junior high school & 59 & 9 & 9 & 50 & 50 \\
$\quad$ Senior high school & 29 & 4 & 4 & 24 & 24 \\
$\quad$ College & & & & & \\
\hline
\end{tabular}


Table 4 (Cont.)

\begin{tabular}{|c|c|c|c|c|c|}
\hline \multirow[t]{3}{*}{ Variable } & \multirow[t]{3}{*}{ Number } & \multicolumn{4}{|c|}{ VIA test result } \\
\hline & & \multicolumn{2}{|c|}{ Positive } & \multicolumn{2}{|c|}{ Negative } \\
\hline & & f & $\%$ & $\mathbf{f}$ & $\%$ \\
\hline \multicolumn{6}{|l|}{ Occupation } \\
\hline Civil officer & 14 & 2 & 2 & 12 & 12 \\
\hline Private employee & 10 & 2 & 2 & 8 & 8 \\
\hline Trader & 4 & 1 & 1 & 3 & 3 \\
\hline Housewife & 43 & 10 & 10 & 33 & 33 \\
\hline Others & 29 & 4 & 4 & 25 & 25 \\
\hline \multicolumn{6}{|l|}{ Family's monthly income } \\
\hline$<$ regional minimum wage & 85 & 15 & 15 & 70 & 70 \\
\hline > regional minimum wage & 15 & 4 & 4 & 11 & 11 \\
\hline \multicolumn{6}{|l|}{ Number of children } \\
\hline $0-2$ & 44 & 5 & 5 & 39 & 39 \\
\hline $3-5$ & 52 & 12 & 12 & 40 & 40 \\
\hline $6-8$ & 4 & 2 & 2 & 2 & 2 \\
\hline \multicolumn{6}{|l|}{ Number of parities } \\
\hline Primigravida & 12 & 2 & 2 & 10 & 10 \\
\hline Multigravida & 88 & 17 & 17 & 71 & 71 \\
\hline \multicolumn{6}{|l|}{ Married age (years) } \\
\hline $17-25$ & 90 & 14 & 14 & 76 & 76 \\
\hline $26-35$ & 10 & 5 & 5 & 5 & 5 \\
\hline \multicolumn{6}{|c|}{ Age at first having children (years) } \\
\hline $17-25$ & 87 & 12 & 12 & 75 & 75 \\
\hline $26-35$ & 13 & 7 & 7 & 6 & 6 \\
\hline \multicolumn{6}{|l|}{ Length of using contraceptives } \\
\hline$<5$ & 14 & 10 & 10 & 4 & 4 \\
\hline$>5$ & & & & & \\
\hline \multicolumn{6}{|l|}{ Type of contraceptives } \\
\hline IUD & 17 & 10 & 10 & 7 & 7 \\
\hline Pills & 9 & 3 & 3 & 6 & 6 \\
\hline Injections & 15 & 3 & 3 & 12 & 12 \\
\hline Implant & 59 & 3 & 3 & 56 & 56 \\
\hline
\end{tabular}

\section{Research Discussion}

Out of 100 respondents who participated in this study, most are early adults. This result is the same as in the study (Lipinwati, 2014). Among the respondents who came to the public health center to do the VIA test were between 25-56 years old. Some of them were still menstruating regularly, but others had menopause. Regarding diseases, age is the significant variable causing disease at all ages. For example, the high risk of HPV infection is prevalent in young women. A small percentage of HPV infections develop into cancer. Thus, early detection of cervical cancer can be performed at any age by adjusting several conditions when carrying out the examination procedures (Nurtini et al, 2018)). WHO recommends early detection at the age of 30-49 years old. If the pre-cancerous lesions are found early during this age, it will reduce cervical cancer incidence and death. During this age, many people are already settled - in a reproductive way. It is the most stable of the reproductive state towards external stimuli, and the period of reproductive function is at its peak (Nugroho, 2010). This study results also follow previous studies stating that $60 \%$ of respondents screened through the VIA test method were 20-35 years old (Juanda, 2015). 
There are $74 \%$ Protestants among the respondents, which is not in line with the previous study (Sunarti, 2016). The previous study said $94.3 \%$ of respondents are Islam. In this case, no research results are showing that specific religion is prone to cervical cancer. Regarding religion, it is a belief people held related to the Almighty God. In some cases, a religious figure, influential and accentuated, has a vital role in encouraging people and increase community participation to take care of their health by being their instructor, mobilizer, motivator, facilitator, or role model.

There are $87 \%$ of respondents are Batak which is not in line with another study (Sunarti, 2016) saying that most respondents suffering from cervical cancer are Javanese. Regarding ethnic, it is a group of people who are identifying themselves with others based on the same lineage. Thus, people living in modern social and cultural heterogeneity will have better knowledge on the VIA test than people living in low heterogeneity and narrow-minded.

There are $98 \%$ of respondents are married. Regarding this marital status, married is a status for people who are bound by marriage, including those legally married or people living together and considered husband and wife by the community. In this case, the support from their life partners (husbands) is vital when the respondents perform the screening test to detect cervical cancer earlier by using the VIA test method (Ilmiah, 2016).

Another factor to be considered is education. It is one of the significant factors supporting people's health knowledge, especially cervical cancer treatment and screening. In this study, 59\% of respondents are high school educated - aligning with the study (Nurtini et al., 2018). There are four elementary school educated women, five junior school educated women, 11 high school educated women, and seven college-educated women. All of them are women of childbearing age. In a study Suartini et al. (2013), the knowledge of women of childbearing age who underwent the VIA test was higher than women who did not undergo the VIA test. Thus, the higher the knowledge, the more participation in carrying out the VIA test. Being educated means it changes one's mindset, especially towards human health. Therefore, the higher the people's education level, the information acceptance regarding health will be different.

Occupation relates to people behaviour towards their health. This is because there are risk factors in certain occupations causing people having diseases. In this study, $43 \%$ of respondents are housewives. Due to this, many women who are not working do screening cancer more often than working women. It is a matter of priority for the women - time and health service (Yuliwati, 2012). If it is based on age, many women took the VIA test was closely related to the age at first marriage. The study results stated that $77.8 \%$ women were 20 years old when having their first marriage. Furthermore, they were less than 20 years old when having their first sexual intercouse making them 10-12 times riskier to have cervical cancer than women aged more than 20 years old. 
The research results also found that most respondents had 3-5 children. Theoretically speaking, more childbirths for a woman means a higher risk of being infected with the HPV virus - causing cervical cancer (Pangesti \& Cokroaminoto, 2012). As for the results based on parity, $88 \%$ of respondents have multigravida. According to another study (Nurtini et al., 2018), 11.1\% had one parity, $48.1 \%$ had two parities, $33.3 \%$ had three parities, and $7.4 \%$ had four parities. The number of parities affects the incidence of cervical cancer. Meanwhile, $88 \%$ of respondents have more than one parity, as the results stated. If a woman gives birth often, she will have a higher risk of cervical cancer due to infection in the genital area. A study Wahyuningsih \& Mulyani (2014) confirmed this result. In that study, women with high parity were three times riskier developing cervical cancer. If a woman gives birth more than three times, she will have a loose birth canal and tore cervical lining, causing open tissue. Thus, a virus will contaminate the opening tissue resulting in infection (Pangesti \& Cokroaminoto, 2012). On the other hand, 90\% of respondents married at the age of late adolescence. Relating to cervical cancer, women who practiced early marriage will have a higher risk of having cervical cancer. The supporting factors of this issue include early age sexual intercourse, having many sexual partners, poor socioeconomic condition, having many deliveries, and other arising external and internal factors.

Another research results stated that women having first sexual intercourse at the age of less than 20 are 10-12 times riskier having cervical cancer than women aged more than 20. In terms of contraceptive use, $86 \%$ of respondents have been using contraceptives for less than five years. As for oral contraceptives, people who use oral contraceptives for more than 4-5 years are prone to cervical cancer 1.5-2.5 times riskier. Several studies show that women using oral contraceptives are more sensitive towards HPV, causing inflammation in their genital area, risking them having cervical cancer (Hidayat, 2017). Oral contraceptive pills are also allegedly causing folate deficiency which reduces mutagen metabolism. Meanwhile, estrogen may be a cofactor generating DNA replication of HPV. In another IARC report, the combined data from eight studies assess the effect of oral contraceptive use upon cervical cancer risk towards HPV-positive women. The researchers found a four-time increase among women using oral contraceptives for more than five years. Women aged less than 20 and using oral contraceptives in the past five years also have an increased risk of cervical cancer.

All respondents have conducted the VIA test. This research result is also based on a theory defining that the higher people knowledge regarding health, they become more aware of having a healthy lifestyle, including women's participation in performing early detection of cervical cancer. This idea is supported by the knowledge's third level covered in the cognitive domain. It is stated that the implementation of knowledge's third level is depicted in the ability to use the studied material in an actual situation or condition. Therefore, women's participation in performing early detection of cervical cancer is the implementation of people's knowledge regarding cervical cancer (Nisah, 2018). 
The results have also shown that most respondents used contraceptives. 59\% of respondents used implant contraceptive, 17\% used IUD, 15\% used injected contraceptive, and 9\% used pill contraceptives. In line with the study (13), $40.7 \%$ of them did not use contraceptives, $7.4 \%$ used condoms while having sex, and $11 \%$ had their husbands performed vasectomy procedure. Along with that, contraceptive is one of the factors causing pre-cancerous lesions if people use it in the long term. For example, oral contraceptive can increase the risk of having cervical cancer by 1.52.5 times higher when using it for more than 4-5 years. Several studies show that women using oral contraceptives are more sensitive towards HPV, causing inflammation in their genital area, risking them having cervical cancer. Regarding contraceptive, it is an attempt to prevent pregnancy. The effect can be temporary or permanent. If it used for a long time, it could be a factor causing cervical lesions.

Also, using hormonal and non-hormonal contraceptives such as IUD is often associated with cervicitis incidence. Due to prolonged use of hormonal contraceptive, it can disrupt the balance of body's estrogen hormone, resulting in abnormal cell changes. Another effect of using an IUD is it can harm the uterus because it is inserted into the uterus and stayed in place for a long time. Thus, women using contraceptives, especially IUD, should maintain their genitalia humidity by keeping it hygienic. If the genital area is wet, do change the underwear immediately twice a day. Do not spray the vagina with perfume/fragrances. It will damage the vagina and disrupt its $\mathrm{PH}$ balance, causing infection (Maharsie, 2012).

The VIA test results showed that 19 women had cervical precancerous lesions. This is supported by the idea that every woman is prone to cervical cancer, yet not all women have the same level of vulnerability. If one detected for precancerous lesion, she should take treatment by carrying out a further test. She can do the further examination in a health service that provides VCT service or Cryoablation method (a freezing method against cancer period).

\section{Research Conclusion}

The VIA test result on women of childbearing age in Patumbak District, Deli Serdang, are primarily negative. Therefore, it is necessary to conduct further research with different variables to obtain more information regarding the causalities of cervicitis incidence. Thus, reducing the incidence numbers of cervical cancer due to improper handle of cervicitis.

\section{REFERENCES}

1. Abduljabbar D, Al-Rawahi F, Faqihi F, Al-Khayat M, Al-Mahmeed M, Al-Khazali M, et al. (2014). Types and risk factors of cervical cancer. Bahrain Med Bull, 36(2):94-6.

2. Aprianti A, Fauza M, Azrimaidalisa A. (2018). Faktor yang Berhubungan dengan Deteksi Dini 
Kanker Serviks Metode IVA di Puskesmas Kota Padang. (2018). J Promosi Kesehat Indonesia. 14(1):68.

3. Dugué PA, Rebolj M, Hallas J, Garred P, Lynge E. (2015). Risk of cervical cancer in women with autoimmune diseases, in relation with their use of immunosuppressants and screening: Population-based cohort study. Int J Cancer. 136(6):E711-9.

4. Farida F. (2017). Penggunaan Alat Kontrasepsi Suntik Dan Pil Terhadap Peningkatan Berat Badan Pada Ibu Pasangan Usia Subur. Str J Ilm Kesehatan. 6(2):43-7.

5. Globocan International Agency for Research on Cancer. The Global Cancer Atlas [Internet]. (2012). Available from: http://globocan.iarc.fr/ia/World/atlas.html

6. Hidayat AAA. (2017) Metode Penelitian Kebidanan dan Teknik Analisis Data. Jakarta: Salemba Medika.

7. Ilmiah P, Lestari IS, Studi P, Masyarakat K, Kesehatan FI, Surakarta UM. (2016). Faktorfaktor yang mempengaruhi kesediaan wus dalam melakukan deteksi dini kanker serviks di puskesmas manahan surakarta.

8. Irianto K. (2014). Gizi Seimbang Dalam Kesehtan Reproduksi (Balanced Nutrition in Reproductive Health). Bandung: Alfabeta.

9. Imelda F, Nasution DL. Correlations among Age, Parity, and Contraception Using with Pap smear Results in Medan Sumtera Sumatera.(2020). Indian J Public Heal Res Dev. 11(6):124751.

10.Juanda D, Kesuma H. Pemeriksaan Metode IVA ( Inspeksi Visual Asam Asetat ) untuk Pencegahan Kanker Serviks. (2015). J Kedokt dan Kesehat [Internet]. 2(2):169-74. Available from: https://ejournal.unsri.ac.id/index.php/jkk/article/view/2549Nurwijaya H. Cegah dan deteksi kanker serviks. Jakarta: Niaga Swadaya.

11.Lipinwati. Diagnosis Molekuler Human Papilloma Virus (HPV) Penyebab Kanker Serviks Lipinwati. Jambi Med J [Internet]. (2014). 2(1):78-86. Available from: https://repository.unja.ac.id/641/1/7 Lipin\%2878-86\%29.pdf.

12.Ministry of Health Republic of Indonesia. (2017). Profil Kesehatan Indonesia. Jakarta.

13. Maharsie L. (2012). Hubungan Pengetahuan Ibu Tentang Kanker Serviks dengan Keikutsertaan Ibu Melakukan IVA Test Di Kelurahan Jebres Surakarta. Gaster J Ilmu Kesehatan. 9(2):46-54.

14.Nisah C. (2018). Pengaruh Pendidikan Kesehatan Terhadap Pengetahuan Dan Sikap Wanita Usia Subur Tentang Pemeriksaan Iva Test. J Media Kesehat. 10(2):111-7.

15.Nova Ari Pangesti1, Cokroaminoto N. (2012). Gambaran Karakteristik Wanita Usia Subur (Wus) Yang Melakukan Pemeriksaan Inspeksi Visual Asam Asetat (Iva) Di Puskesmas Karanganyar. J Ilm Kesehat Keperawatan [Internet]. 8(1):81-94. Available from:http://download.portalgaruda.org/article.php?article=65825\&val=4792\&title=GAMBA RAN KARAKTERISTIK WANITA USIA SUBUR (WUS) YANG MELAKUKAN PEMERIKSAAN INSPEKSI VISUAL ASAM ASETAT (IVA) DI PUSKESMAS KARANGANYAR. 
16.Nugroho. (2010). Deteksi kanker serviks dengan metode IVA. Jakarta: Niaga Swadaya.

17.Nurtini NM, Dewi KP, Puspita Dewi NWE. (2018). Karakteristik Wanita Usia Subur Yang Melakukan Inspeksi Visual Asam Asetat Di Kelurahan Renon. J Ris Kesehatan Nasional. $1(1): 42$.

18.Nurwijaya H. (2010). Cegah dan deteksi kanker serviks. Jakarta: Niaga Swadaya.

19.Setiawati E, Handayani OWK, Kuswardinah A. (2017). Pemilihan Kontrasepsi Berdasarkan Efek Samping Pada Dua Kelompok Usia Reproduksi. Unnes J Public Health. 6(3):167.

20.Sunarti NTS. (2016). Deteksi Dini Kanker Serviks: Studi Cross Sectional Pada Ibu Rumah Tangga Di Pedesaan. J Kesehatan Samodra Ilmu. 07(02):133-41.

21.Suarniti NW, Setiawan, Tasya M. (2013). Pengetahuan Dan Motivasi Wanita Usia Subur Tentang Tes Inspeksi Visual Asam Asetat Di Propinsi Bali Indonesia. Fakultas Kedokteran Universitas Padjadjaran.

22. Yuliwati. (2012). Faktor-Faktor Yang Berhubungan Dengan Perilaku WUS Dalam Deteksi Dini Kanker Leher Rahim Metode IVA Di Wilayah Puskesmas Prembun Kabupaten Kebumen. Universitas Indonesia.

23.Wahyuningsih T, Mulyani EY. (2014). Faktor Resiko Terjadinya Lesi Prakanker Serviks Melalui Deteksi Dini Dengan metode IVA. Forum Ilm [Internet]. 11:192-209. Available from:https://pdfs.semanticscholar.org/7cec/fd7471078e1b687d1601d8090ff160f9fb8b.pdf 